\title{
Effect of osmopriming on rice seed germination and seedling growth
}

\author{
R. Islam, A. Mukherjee and M. Hossin \\ Agrotechnology Discipline, Khulna University, Khulna-9208, Bangladesh. E-mail: a.mukherjee@irri.org.
}

\begin{abstract}
The experiment was conducted in the Agronomy Laboratory of Agrotechnology Discipline, Khulna University, Khulna from 29th August to 17th September, 2009. The experiment was laid out in a Completely Randomized Design (CRD) with two factors and three replications. The aim of the experiment was to study the efficacy of three osmopriming agents viz ., $\mathrm{NaCl}, \mathrm{KCl}$ and $\mathrm{CaCb}$ with control on seed germination and seedling growth of three T. aman rice varities viz., BRRI dhan40, BRRI dhan41 and BINA dhan7. Among the chemicals $\mathrm{CaCb}$ showed best as osmopriming agents and it enhanced all germination parameters. BRRI dhan41 showed the best performance. Better root length and shoot length were observed in control. Seeds of BRRI dhan41 when treated with $\mathrm{NaCl}$ showed the highest germination percentage (98.67\%), germination energy (88\%), germination speed (96.83\%), but vigor index (10.63) was found highest in BRRI dhan40 when it was treated with KC1. BRRI dhan41 produced the largest root $(8.56 \mathrm{~cm})$ when seeds were treated with $\mathrm{NaCl}$. BRRI dhan40 $(10.51 \mathrm{~cm})$ and BINA dhan7 $(10.53 \mathrm{~cm})$ produced the highest shoot length at controlled condition and $\mathrm{CaCl} 2$ treated seed, respectively.
\end{abstract}

Keywords: Osmopriming, Rice, Germination, Seedling growth

\section{Introduction}

Rice (Oryza sativa L.) is the most important and extensively cultivated cereal crops in Bangladesh. Rice has been considered as staple food of the Bangladeshi people about $80 \%$ of the total cultivated lands in Bangladesh are used for rice cultivation and its total production is 31.98 million metric tons (BBS, 2011). Rice supplies more than $70 \%$ of calories (Khush, 2008) and more than 50\% proteins (Islam, 2009) as well as contributes $95 \%$ of the cereals consumed in Bangladesh.

Good seed germination behavior is very important for field crops. Uneven or poor germination and subsequently uneven seedling growth can lead to great financial losses, by reducing crop production or lower prices of uneven plant batches (Ghiyasi et al., 2008a). But seed priming can increase speed and uniformity of germination (Ghiyasi et al., 2008b). Seed priming treatments can lead to better germination and establishment in many crops such as maize, wheat, rice, canola (Basra et al., 2005; Ghiyasi et al., $2008 a, b)$. In another way seed priming could be defined as controlling the hydration level within seeds so that the metabolic activity necessary for germination can occur but radical emergence is prevented. Different physiological activities within the seed occur at different moisture levels (Taylor, 2007). The last physiological activity in the germination process is radical emergence. The initiation of radical emergence requires high seed water content.

Once sown, seeds spend significant amounts of time just absorbing water from the soil. By reducing this time to a minimum seeds can be made to germinate and seedlings emerge. The quicker to do this is to soak seeds in water before sowing. It has been reported that primed crop seeds emerged faster and grew more vigorously. They also flowered earlier very important in drought-prone areas, matured earlier and gave higher yields. Priming has, therefore, become very popular and it is simple and cheap yet extremely effective (Broud et al., 2006).

Several different priming methods have been reported to be used commercially. Among them, liquid or osmotic priming is a very common practice. It is well established that seed soaking in chemical improve the crop performance over control, particularly under adverse conditions. Many workers have studied the effect of seed treatment with different chemicals and found that crops yield can be increased through presowing treatments with chemicals (Mehortra et al., 2005). One of the primary benefits of priming has been the extension of the temperature range at which a seed can germinate (Valdes and Bradford, 1987). 
From a practical standpoint, priming enables seeds of several species to germinate and emerge at supraoptimal temperatures. Priming has also alleviated secondary dormancy mechanisms that can be imposed if exposure to supra-optimal temperatures lasts too long (Valdes et al., 1985). The other benefit of priming has been to increase the rate of germination at any particular temperature. On a practical level, primed seeds emerge from the soil faster and often more uniformly than non-primed seeds because of limited adverse environmental exposure. Priming accomplishes this important development by shortening the lag or metabolic phase or phase II in the triphasic water uptake pattern (Bewley and Black, 1978) in the germination process. The metabolic phase occurs just ater seeds are fully imbibed and just prior to radical emergence. Since seeds have already gone through this phase during priming, germination times in the field can be reduced by approximately 50\% upon subsequent rehydration. Moreover priming has been commercially used to eliminate or greatly reduce the amount of seed-borne fungi and bacteria. Organisms such as Xanthomonas campestris in Brassica seeds and Septoria clearly have been shown to be eliminated within seed lots as a by-product of priming (Bachman, 1989). In the case of Xanthomonas campestris in Brassica sp., zero infection in 50,000 seeds is commonly reported (Goustine, 2004). So. considering above, the experiment was conducted with the following objectives:

To observe the efficiency of different chemicals as osmopriming materials on rice seed germination and seedling growth. To observe the varietal response against different osmopriming agents.

\section{Materials and Methods}

The experiment was conducted in the Agronomy Laboratory of Agrotechnology Discipline, Khulna University, Khulna from 29th August to 17th September, 2009. The materials used in the study and methodologies followed presented in this chapter in systematic ways.

\section{Treatments}

There are two factors -

\begin{tabular}{|l|l|}
\hline Factor A- Salt solutions & Factor B- Rice varieties \\
\hline $\mathrm{S}_{1}=$ control (water) & Aman rice vaities-3 \\
$\mathrm{S} 2=16.4 \mathrm{~g} / \mathrm{L} \mathrm{NaCl}$ & V1=BRRI dhan40 \\
$\mathrm{S} 3=20.74 \mathrm{~g} / \mathrm{L} \mathrm{KC1}$ & V2=BRRIdhan41 \\
$\mathrm{S} 4=22.2 \mathrm{~g} / \mathrm{L} \mathrm{CaCl} 2$ & V3=BINA dhan7 \\
\hline
\end{tabular}

The expeiment was laid out in a Completely Randomized Design (CRD) with two factors and four replications.

Total number of petridishes were $=3$ (Vaities) $\times 4$ (Solutions) $\times 4$ (Replication) $=48$

Three different concentration of $\mathrm{NaCl}, \mathrm{KC} 1$ and $\mathrm{CaCl} 2$ were used in the study as osmopiming agent Solution of $16.4 \mathrm{~g} \mathrm{NaCl}, 20.74 \mathrm{~g} \mathrm{KC} 1$ and $22.2 \mathrm{~g} \mathrm{CaCl} 2$ were taken respectively in each of a $1000 \mathrm{ml}$ Volumetric flask and filled up to a mark with distilled water. Then, a weighed quantity of seed ( $250 \mathrm{~g}$ ) each of three varieties were soaked in solution having $16.4 \mathrm{~g} / 1 \mathrm{NaCl}, 20.74 \mathrm{~g} / 1 \mathrm{KC} 1,22.2 \mathrm{~g} / 1 \mathrm{CaCl} 2$ and with distilled water respectively for 24 hours at $25 \pm 2{ }^{\circ} \mathrm{C}$. The ratio of seed weight to solution volume was 1:5. (Bashra et al., 2004; Farooq et al., 2004).

\section{Germination Test}

The germination test was conducted using the Petridish method. Two pieces of blotting papers were used in each Petridis as substrate. Twenty five seeds of BRRI dhan 40, BRRI dhan 41and BINA dhan 7 were placed in each medium size Petridish. Each treatment was replicated four times. The solutions were used for germination of seeds and distilled water was used in control. The petridishes were observed every day. 


\section{Data collection}

Germination Parameters: The petidishes were observed every day and the numbers of germinated seeds were recorded. After one dav of seed setting in petidishes, few of the seeds were terminated. Within 4 davs after seed setting in petridishes maximum number of seeds were germinated. A seed was considered to be germinated as seed coat ruptured, plumule and radicle came out and were $>2 \mathrm{~mm}$ long. Germination count was expressed in percentage. The germination percentage was calculated using the following formula-

Germination $(\%)=\frac{\text { Number of seed germinated }}{\text { Total number of seeds set for test }} \times 100$

The speed of germination (\%) was calculated using the following formula (Krishnaswamy and Seshu, 1990).

Speed of germination $(\%)=\frac{\text { Number of seed germinated at } 72 \mathrm{~h}}{\text { Number of seeds germinated at } 168 \mathrm{~h}}$

Germination energy = Percentage of seeds germinated at $72 \mathrm{~h}$ (Bam et al., 2006).

Vigor Index $=$ No. of germinated seeds $/$ days of first count $+\ldots \ldots+$ No. of germinated seeds/days at final count.

\section{Measurement of Root and Shoot Length}

Randomly selected five seedlings were taken from each petridish to measure root and shoot length. It was measured with a measuring scale and expressed in centimeters. Root and shoot length of the seedlings were measured after 17 days of seed setting (kouio, 2003).

\section{Measurement of Fresh Weight and Dry Weight of the Seedling}

After 17 days of seed setting 15 seedlings of each petisdish were wrapped with brown paper and weighed the fresh weight first and then they were died in oven at $70^{\circ} \mathrm{C}$ for 48 hours and weighed the dry weight. These were measured by four digit balance and expressed in gram.

\section{Statistical Analysis}

All the data were analyzed by using MSTAT-C (Statistical analysis software) computer package program. The differences between the treatment means were determined by using Duncan's Multiple Range (DMRT) (Gomez and Gomez, 1984).

\section{Results and Discussion}

Effect of Rice varieties: All the germination parameters of three rice varieties BRRI dhan40, BRRI dhan41 and BINA dhan7 were presented in Table 1. Among the varieties germination percentage, germination energy (\%) and germination speed (\%) varied widely. The highest germination percentage, termination energy (\%) and germination speed was found from BRRI dhan41 and it was 93.67\%, 78\%and $83.72 \%$ respectively. Significant difference was seen in fresh weight of varieties. 
Table 1. Varietal differences related to germination parameters among three $\mathrm{T}$. ama rice varieties as affected by seed priming

\begin{tabular}{|l|c|c|c|c|}
\hline Varieties & $\begin{array}{c}\text { Germination } \\
(\%)\end{array}$ & $\begin{array}{c}\text { Germination } \\
\text { energy (\%) }\end{array}$ & $\begin{array}{c}\text { Germination speed } \\
(\%)\end{array}$ & $\begin{array}{c}\text { Germination } \\
\text { index }\end{array}$ \\
\hline BRRI dhan40 & $92.33 \mathrm{ab}$ & $75.33 \mathrm{c}$ & $80.64 \mathrm{c}$ & 9.52 \\
\hline BRRI dhan41 & $93.67 \mathrm{a}$ & $78.00 \mathrm{a}$ & $83.72 \mathrm{a}$ & 9.18 \\
\hline BINA dhan7 & $87.33 \mathrm{c}$ & $76.67 \mathrm{~b}$ & $82.44 \mathrm{~b}$ & 9.06 \\
\hline CV (\%) & 1.88 & 4.13 & 5.54 & 2.06 \\
\hline Level of significance & 0.01 & 0.01 & 0.01 & $\mathrm{NS}$ \\
\hline
\end{tabular}

Figures in a column with similar letter (s) do not differ significantly

$\mathrm{CV}=$ Co-efficient of variation

Interaction effect of varieties and osmopriming agents: Seed germination parameters eg. germination percentage, germination energy (\%), germination speed (\%) greatly varied due to interaction of rice varieties and osmopriming agents (Table 2). The highest germination (98.67\%) was found in the treatment $V_{1} S_{1}$ i.e BRRI dhan40 in control condition which was statistically similar with $V_{1} S_{2}, V_{1} S_{3}$, $\mathrm{V}_{2} \mathrm{~S}_{2}, \mathrm{~V}_{2} \mathrm{~S}_{3}, \mathrm{~V}_{3} \mathrm{~S}_{4}$ and $\mathrm{V}_{2} \mathrm{~S}_{4}$. In case of germination energy (\%) and germination speed (\%), BRRI dhan41 performed better in $\mathrm{NaCl}$ treated seeds. It was due to salt tolerant ability of BRRI dhan41 (K. Bashar, 2008).

Table 2. Interaction effect of variety and different osmopriming agents on germination of three T.aman rice varieties

\begin{tabular}{|l|l|c|c|c|c|}
\hline Variety & Salt Conc. g/L & Germination & $\begin{array}{c}\text { Germination } \\
\text { Energy (\%) }\end{array}$ & $\begin{array}{c}\text { Germination } \\
\text { Speed (\%) }\end{array}$ & Vigor Index \\
\hline BRRI dhan 40 & Control (water) & $98.67 \mathrm{a}$ & $84.00 \mathrm{ab}$ & $69.55 \mathrm{~d}$ & $7.86 \mathrm{~d}$ \\
\hline BRRI dhan 40 & S2=16.4g/L NaCl & $94.67 \mathrm{ab}$ & $56.00 \mathrm{c}$ & $89.23 \mathrm{bc}$ & $10.06 \mathrm{~b}$ \\
\hline BRRI dhan 40 & S3=20.74 g/L KC1 & $98.67 \mathrm{a}$ & $86.67 \mathrm{a}$ & $76.73 \mathrm{~cd}$ & $10.63 \mathrm{a}$ \\
\hline BRRI dhan 40 & S4=22.2 g/L CaCl2 & $82.67 \mathrm{de}$ & $74.67 \mathrm{~b}$ & $75.67 \mathrm{~cd}$ & $9.32 \mathrm{bc}$ \\
\hline BRRI dhan 41 & Control (water) & $77.33 \mathrm{c}$ & $63.33 \mathrm{cb}$ & $85.61 \mathrm{abc}$ & $7.69 \mathrm{~d}$ \\
\hline BRRI dhan 41 & S2=16.4g/L NaCl & $98.67 \mathrm{a}$ & $88.00 \mathrm{a}$ & $96.83 \mathrm{a}$ & $9.91 \mathrm{bc}$ \\
\hline BRRI dhan 41 & S3=20.74 g/L KC1 & $97.33 \mathrm{ab}$ & $82.67 \mathrm{ab}$ & $85.00 \mathrm{bc}$ & $9.83 \mathrm{bc}$ \\
\hline BRRI dhan 41 & S4=22.2 g/L CaCl2 & $96.00 \mathrm{ab}$ & $78.67 \mathrm{ab}$ & $81.86 \mathrm{bc}$ & $9.28 \mathrm{bc}$ \\
\hline BINA dhan 7 & Control (water) & $77.33 \mathrm{e}$ & $58.66 \mathrm{c}$ & $75.96 \mathrm{~cd}$ & $7.70 \mathrm{~d}$ \\
\hline BINA dhan 7 & S2=16.4g/L NaCl & $92.00 \mathrm{be}$ & $64.67 \mathrm{c}$ & $89.00 \mathrm{ab}$ & $9.33 \mathrm{bc}$ \\
\hline BINA dhan 7 & S3=20.74 g/L KC1 & $86.67 \mathrm{~cd}$ & $84.00 \mathrm{ab}$ & $88.77 \mathrm{ab}$ & $9.98 \mathrm{bc}$ \\
\hline BINA dhan 7 & S4=22.2 g/L CaCl2 & $93.33 \mathrm{ab}$ & $84.00 \mathrm{ab}$ & $74.21 \mathrm{~cd}$ & $9.20 \mathrm{c}$ \\
\hline CV (\%) & 4.45 & 6.54 & 7.53 & 0.72 \\
\hline Level of significance & 0.01 & 0.01 & 0.01 & 0.01 \\
\hline
\end{tabular}

Figures in a column with similar letter (s) do not differ significantly Interaction of varieties and osmopriming agents on root growth, shoot growth, fresh weight and dry weight was presented in Table 3 . The highest root length was measured in BRRI dhan41 $(8.56 \mathrm{~cm})$ seeds treated with $\mathrm{NaCl}$ solution. This is statistically similar with treatment $\mathrm{V}_{3} \mathrm{~S}_{3}$. Shoot length of BRRI dhan40 showed better response to all osmopriming agents. Higher shoot length was observed in BINA dhan7 seedling where seed treated with $\mathrm{CaCl} 2$ solution which was followed by $\mathrm{V}_{3} \mathrm{~S}_{3}, \mathrm{~V}_{3} \mathrm{~S}_{1}, \mathrm{~V}_{2} \mathrm{~S}_{2}$ and $\mathrm{V}_{3} \mathrm{~S}_{2}$. The highest fresh and dry weight was recorded in the treatment $V_{3} S_{1}$ i.e. BINA dhan7 in control condition. 
Table 3. Interaction effect of variety and different osmopriming agents on root length, shoot length, fresh weight and dry weight of three T.aman rice varieties

\begin{tabular}{|c|c|c|c|c|c|}
\hline Variety & Salt Conc. g/L & $\begin{array}{l}\text { Root length } \\
\text { (cm) }\end{array}$ & $\begin{array}{l}\text { Shoot length } \\
\text { (cm) }\end{array}$ & $\begin{array}{c}\text { Fresh weight } \\
\text { (g) }\end{array}$ & $\begin{array}{l}\text { Dry weight } \\
\text { (g) }\end{array}$ \\
\hline BRRI dhan 40 & Control (water) & 4.82cdef & $10.51 \mathrm{a}$ & $1.19 \mathrm{~d}$ & 0.11 cdde \\
\hline BRRI dhan 40 & $\mathrm{~S} 2=16.4 \mathrm{~g} / \mathrm{L} \mathrm{NaCl}$ & 4.95def & $10.07 a$ & $1.22 \mathrm{~d}$ & $0.18 \mathrm{cde}$ \\
\hline BRRI dhan 40 & $\mathrm{~S} 3=20.74 \mathrm{~g} / \mathrm{L} \mathrm{KC1}$ & 5.28def & $10.66 a$ & $1.26 \mathrm{~cd}$ & $0.19 a b$ \\
\hline BRRI dhan 40 & $\mathrm{~S} 4=22.2 \mathrm{~g} / \mathrm{L} \mathrm{CaCl} 2$ & 5.94cde & $10.00 \mathrm{a}$ & $1.37 \mathrm{bcd}$ & $0.15 \mathrm{bcd}$ \\
\hline BRRI dhan 41 & Control (water) & $3.76 f$ & $4.66 \mathrm{~d}$ & $1.39 \mathrm{bcd}$ & $0.077 \mathrm{e}$ \\
\hline BRRI dhan 41 & $\mathrm{~S} 2=16.4 \mathrm{~g} / \mathrm{L} \mathrm{NaCl}$ & $8.56 a$ & $8.55 a b$ & $1.48 \mathrm{bc}$ & $0.15 \mathrm{bcd}$ \\
\hline BRRI dhan 41 & $\mathrm{~S} 3=20.74 \mathrm{~g} / \mathrm{L} \mathrm{KC1}$ & $4.56 \mathrm{ef}$ & $5.59 \mathrm{~cd}$ & $1.47 \mathrm{bc}$ & 0.12 cde \\
\hline BRRI dhan 41 & $\mathrm{~S} 4=22.2 \mathrm{~g} / \mathrm{L} \mathrm{CaCl} 2$ & $4.34 f$ & $7.53 \mathrm{bc}$ & $1.49 \mathrm{bc}$ & $0.16 \mathrm{bc}$ \\
\hline BINA dhan 7 & Control (water) & $7.03 \mathrm{bc}$ & $9.43 a b$ & $1.79 \mathrm{a}$ & $0.24 a$ \\
\hline BINA dhan 7 & $\mathrm{~S} 2=16.4 \mathrm{~g} / \mathrm{L} \mathrm{NaCl}$ & 5.15def & $8.43 a b$ & $1.36 \mathrm{bcd}$ & $0.14 \mathrm{bcd}$ \\
\hline BINA dhan 7 & $\mathrm{~S} 3=20.74 \mathrm{~g} / \mathrm{L} \mathrm{KC1}$ & $7.44 a b$ & $9.53 a b$ & 1.34bcd & 0.09de \\
\hline BINA dhan 7 & $\mathrm{~S} 4=22.2 \mathrm{~g} / \mathrm{L} \mathrm{CaCl} 2$ & $6.41 \mathrm{bcd}$ & $10.53 a$ & $1.56 \mathrm{~b}$ & $0.16 \mathrm{bc}$ \\
\hline \multicolumn{2}{|l|}{ CV (\%) } & 14.34 & 13.50 & 9.16 & 14.36 \\
\hline \multicolumn{2}{|c|}{ Level of significance } & 0.01 & 0.01 & 0.01 & 0.01 \\
\hline
\end{tabular}

Figures in a column with similar letter (s) do not differ significantly

\section{Summary and Conclusion}

Among the varieties germination percentage, germination energy (\%) and germination speed (\%) varied widely. The highest germination percentage, germination energy (\%) and germination speed was found from BRRI dhan 41 and it was $93.67 \%, 78 \%$ and $83.72 \%$ respectively.

From the findings of the present study it might be concluded that

$>$ Among the osmopriming agents Calcium chloride $(\mathrm{CaCl} 2)$ showed the best activity in regard to seed germination (\%), germination energy (\%), germination speed (\%) and germination index.

$>\quad$ It was observed that BRRI dhan41 treated with $\mathrm{NaCl}$ gave the best germination (\%), germination energy (\%), germination speed (\%) and root length.

\section{References}

Bam, R.K., Kumaga, F.K., Ori, K. and Asiedu, E.A. 2006. Germination, vigour and dehydrogenase activity of naturally aged rice (Oryza sativa L.) seeds soaked in potassium and phosphorus Asian Journal of Plant Sciences 5(6): 948-955.

Basara, S.M.A, M. Farooq, Tabassum and Ahmad, N. 2005. Physiological and biochemical aspect pre- sowing seed treatments in fine rice ( Oryza sativa L.). Seed Science Technology. 33:623-628.

Bshar, K.M. 2008. Seed treatment for vigor, viability productivity.IndianFmg., 72:27-28.

BBS. 2011. Monthly Statistical Bulletin, Bangladesh (July, 2011). Bangladesh Bureau of Statistics, Statistics Division, Ministry of Planning. Government of the Peoples' Republic of Bangladesh. pp 607-615.

Broud, K.P. 2006."Mineral Nutrition of higher plant" (Second Edn.). Academic Press, London.

Bewley, L.M and Black, M.N. 1978. Salinity effects on growth and development of rice, physiological changes. Pesquisa Agropecuaria Brasileira, 24(9): 1111-1118.

Ghiyasi, M., Seyahjam, A.A., Tajbakhs, M., Amrma, R. and Hojat Salehzade. 2008. Effect of osmopriming with polyethylene glycol (8000) on germination and seedling growth of wheat (Triticum aestivum L.) seeds under salt stress. Journal of Biological. Science. 3(10): 1249-1251.

Gomez, A.K. and Gomez, A.A. 1984. Statistical procedures for agricultural research 2nd ed. International Rice Research Institute, Los Banos, Philippines, pp 207-215.

Goustin,C.I. 2004. Seed treatment and measurement of germination Speed. Journal of seed science uk Press. Pp406-460. 
Islam, K.T. 2009. Effects of priming on germination and health of rice (Oryza sativa L.) seeds Seed science and technology, vol. 30. Khush, G.S. 2008. Origin, dispersal, cultivation and variation of rice. Journal of Plant Molecular Biology. 35: 25-34.

Krishnaswamy, V. and Seshu, D.V. 1990. Germination after accelerate aging and associated characters in rice varieties. Seed Science and Technology, 18: 147-15.

Kouio, A.G. 2003. Chemical and biological changes in seed treatment of rice varietis. Journal of rice Science. International Rice Research Institute, Los Banos, Philippines, pp 207-215.

Mel Bachman, C.L. 1989. Speed of germination-aid in selection and evaluation for seedlingemmergence and vigour. Journal of Crop Science 2: 176-177.

Mohetra.T.h and Ramiah, K. 2005. Treatment of rice seed in nutrient solution as means of increasing yield. Journal of Biological Science. 20:270-271.

Taylor, I.J. 2007. Displacement of $\mathrm{Ca}^{2+}$ by $\mathrm{Na}^{+}$from the plasmalemma of root cells. A primary response to salt stress. Journal of Plant Physiology 79: 207-211.

Valdes, V.M., Bradford, K.J. and Mayberry, K.S. 1985. Alleviation of thermo-dormancy in coated lettuce seeds by seed priming. Journal of Horticulture Science 20: 1112-1114. 